The actual amount of light falling on the coal face was measured in several collieries, and the average of a large number of observations is given below.

In five open light collieries the average illumination at the coal face was 0.09 of a foot-candle. In eight safety lamp collieries the average illumination was 0.018 of a footcandle, or only one-fifth of that obtaining in an open light mine.

The questions of the influence of holing and illumination have been discussed separately, and the following table has been drawn up to show the relation they bear to one another.

TABLE IX.-Holing and Illumination.

\begin{tabular}{|c|c|c|c|c|c|}
\hline District. & Holing. & $\begin{array}{l}\text { Position } \\
\text { at Work. }\end{array}$ & $\begin{array}{l}\text { Thickness } \\
\text { of Seam. }\end{array}$ & Light. & $\begin{array}{l}\text { Incidence of } \\
\text { Nystagmus. }\end{array}$ \\
\hline Eomerset .. & Much & On side & $\underset{1 \frac{1}{2}-3 \frac{1}{2}}{\text { Feet. }}$ & Candles & Unknown \\
\hline Forest of Dean ... & Much & On side & $2-4$ & Candles & Unknown \\
\hline $\begin{array}{l}\text { Open light pits, } \\
\text { Sonth Wales }\end{array}$ & Much & Side or & $2^{\frac{1}{2}}-$ & Candles & Rare \\
\hline $\begin{array}{l}\text { Safety lamp pits, } \\
\text { South Wales }\end{array}$ & None & $\begin{array}{l}\text { Knees or } \\
\text { standing }\end{array}$ & $3 \frac{1}{2}-$ & Safely & Common \\
\hline Midla & Much & & $5-7$ & Lan & Common \\
\hline
\end{tabular}

The Personal Factor.

The personal factor remains to be considered, and it is now recognized by a large number of surgeons that ocular defects play an important part in determining whether a man should have nystagmus or not. The result of my investigations is given below :

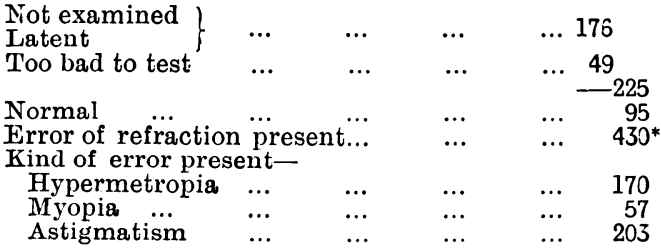

* $=81.9$ per cent. of cases examined.

It must be remembered that a small error of refraction is common in normal people.

Accident and ill health are also determining factors. In 146 cases there was a history of an accident-in 73 cases to the eye, in 43 cases to the head, and in 30 cases the injury was general. In North Staffordshire accidents to the eye occur very frequently before the onset of nystagmus. In the first 600 cases seen there was a history of accident to the eyes in 36 cases; in the last 150 cases, all from North Stafford, there has been injury to the eyes in 37 cases.

\section{Preventive Treatment.}

It is in the first place necessary to improve the miners' lamp, and the mining engineer must no longer be content with an average illumination of one-fiftieth of a foot-candle at the coal face. The introduction of electric lamps into general use is probable, as it seems unlikely sufficient light can be obtained in any other way. The elimination of unfit workmen by medical examination before employment would also be of the greatest service. Efficient ventilation and any hygienic measures will also help.

\section{AMINO-ACIDS AND SUGARS IN RECTAL FEEDING.**$$
\text { BY }
$$

A. RENDLE SHORT, M.D., B.S., B.Sc., F.R.C.S., DEMONSTRATOR OF PHYSIOLOGY IN THE UNIVERSITY OF BRIBTOL; ASSISTANT SURGEON, ERISTOL ROYAL INFIRMAIY ;

$$
\text { AND }
$$

H. W. BYWATERS, D.Sc., Ph.D., F.I.C., A.R.C.Sc., DEMONSTRATOR OF PHYSIOLOGY IN THE CNIVERSITY OF BRISTOL.

(From the Physiological Laboratory of the University of Bristol.)

IN spite of its great drawbacks, "feeding" by nutrient enemata is in almost universal use at the present time. -During the past few years, however, the advance in our Imowledge of the ordinary processes of absorption from the bowel makes it necessary to review the experimental

* Part of the expenses of this research has beendefrayed by a grant from the Colston Research Fund. and clinical evidence on which the practice of rectal feeding is based. We hope to demonstrate that, as at present practised, it is nearly useless, but that it is possible considerably to enhance its value in most cases.

\section{History of Rectal Feeding.}

An excellent summary of the older history is given by Gros. Galen and Celsus both practised it, and it was in fairly frequent use during the Middle Ages. Ramazini, in the seventeenth century, claims to have kept a girl alive by its means for seventy days.

The classical researches on the subject, on which the modern practice is based, are those of Ewald and Leube. In 1872 Leube kept a dog alive for months on injections of chopped meat and pancreas, claiming an absorption equivalent to 500 calories daily. Ewald in 1887 published tables purporting to show the results of administering egg and peptone enemata, which appear to demonstrate great absorption, but his experimental methods were unsatisfactory (for example, he used phenolphthalein as an indicator for ammonia) and the data inadequate. Later workers (Huber, Bial, Sharkey, Plantenga, Edsall and Miller, Mutch and Ryffel) all report a small but variable absorption of albumen and peptone.

All the above observations were made by the "wash. out" method, the enemata given one day being washed out next morning by rectal lavage, and it being assumed that what could not be recovered from the washing must have been absorbed.

Boyd and Robertson, whose tables we shall presently examine, appeared to have reposed confidence in the "wash-out" method, but they also analysed the nitrogen excretion in the urine. Langdon Brown criticized the "wash-out" method and trusted to the urinary analysis. He found practically no absorption of peptone.

The data for the absorption of sugar and fat will be discussed later.

\section{The Absorption of Proteins.}

We have seen that many observers, trusting to the "wash-out" method, have reported a small, variable degree of absorption of albumen and peptone, the latter giving the better results. As a type of these observations we may examine the careful and detailed figures supplied by Boyd and Robertson, who also made urinary analyses for nitrogen by Kjeldahl's method. Seven young women suffering from gastric ulcer were fed entirely on nutrient enemata for six or seven days. They were kept in bed, and weighed before and after. All did well clinically. The enemata were given six-hourly, and consisted of two eggs or 200 c.cm. of milk and egg, dextrose, nörmal saline, and in one case cod-liver oil. The whole was pancreatized for twenty minutes. Every day the bowel was washed out, and the contents analysed.

Results of Analyses.

\begin{tabular}{ll|c|c|c}
\hline & & $\begin{array}{c}\text { Loss or Gain of } \\
\text { Weight in Kilos. }\end{array}$ & $\begin{array}{c}\text { Total N Disap- } \\
\text { peared from Bowel. }\end{array}$ & $\begin{array}{c}\text { Total N } \\
\text { in Urine. }\end{array}$ \\
\hline Case I (6 days) & $\ldots$ & -2.27 & $\begin{array}{c}\text { Grams. } \\
9.26\end{array}$ & $\begin{array}{c}\text { Grams. } \\
19.66\end{array}$ \\
Case II (6 days) & $\ldots$ & -1.475 & 6.59 & 33.04 \\
Case III (7 days) & $\ldots$ & -2.837 & 11.93 & 18.81 \\
Case IV (7 days) & $\ldots$ & -3.632 & 4.33 & 44.21 \\
Case V (7 days) & $\ldots$ & -4.086 & 9.70 & 48.13 \\
Case VI (7 days) & $\ldots$ & -5.448 & 15.60 & 56.87 \\
Case VII (6 days) & $\ldots$ & +0.227 & -0.17 & 42.19
\end{tabular}

It will be observed that in every case the amount of nitrogen absorbed from the bowel could not possibly account for that lost by the urine, even if we admit that disappearance from the bowel means absorption by the patient. As Langdon Brown has pointed out, this is very improbable. Patients who are having daily rectal washes may pass a huge putrid stool, which presumably came from the caecum and was not touched by the lavage. The physiological antiperistalsis of the colon may carry the remains of the nutrient enema up beyond the reach of the wash, and so it will disappear from the rectum and yet not be absorbed, but putrefy. 
Boyd and Robertson's own figares demonstrate this forcibly. If disappearance of nitrogen from the rectum means absorption, then the nitrogen excretion in the urine will run parallel. It does not. In Case III, where the urinary nitrogen is lowest, the apparent absorption was best but one. In Case vir, though the absorption was nil, the urinary output is above the average.

If it is accepted that the wash-out method is totally unreliable, as we maintain, the whole question of the value of rectal feeding with proteins requires fresh consideration. It emerges very badly from the examination; it is not going too far to say that the quantity absorbed is quite insignificant.

It may be argued that as patients can be kept alive for weeks on nutrient enemata, and the loss of weight is often very small, therefore the clinical evidence of their value is conclusive, and cannot be upset by physiological experimentation. This reasoning is quite fallacious. Men have lived as long as sixty-four days with no food at all, and if a patient is kept warm in bed, supplied with plenty of fluid, and given absorbable sugars by the rectum, it is not surprising that he may: live for weeks on perfectly useless nitrogenous enemata. All clinicians know, however, that it is impossible to restore patients to strength or vigour by rectal feeding, and they are liable to sudden collapse, and even death.

It is certainly remarkable that so little weight is lost. Gros shows that even after a month the average loss is only about 4 kilos. Boyd and Robertson's cases, during a week of abstinence from food by mouth, lost weight varying from 1.475 to 5.448 kilos. More remarkable still are the cases in which there is an actual gain in weight. This, however, by no means proves that nitrogen is absorbed. In the only patient of the Scottish observers who gained a trifle, they admit that absolutely no nitrogen disappeared from the rectal washings ; in fact, more was recovered than they injected. Langdon Brown has shown that a gain of weight is possible when nothing is given but normal saline per rectum.

The patients on whom observations have been made were almost all young women who had suffered from severe haematemesis and were exsanguinated in consequence. The gain of weight is, in our opinion, probably due to absorption of water to replace the blood lost. In Boyd and Robertson's series it was the patient who had lost most blood who gained in weight.

Again, it may be argued that even if the rectum is not able to absorb protein, antiperistalsis will carry the enema through the ileo-caecal valve into the small intestine. Gros quotes Gilles do la Tourette's famous cases, in which hysterical persons have vomited enemata. These oc currences are, however, highly exceptional. We now know from the employment of skiagraphy after bismuth enemata that in the great majority of cases the injection gets no further than the colon or caecum.

We believe that very little, if any, nitrogen is absorbed from nutrient enemata as ordinarily prepared, on the following grounds:

1. The nitrogen output in the urine of persons "fed" on peptonized proteins is little, if any, higher than that in the urine of professional fasting men or of patients receiving only normal saline per rectum.

2. Analyses of the differences in the amount of nitrogen in the alimentary contents- $(a)$ at the ileo-caecal valve, (b) in the faeces passed per anum-show little or no absorption by the rectum (Groves and Walker Hall). These observations were made on patients with a rightsided colostomy.

3. We know that patients lose strength instead of gaining it on rectal feeding. It can never be relied on, for instance, to build up a patient with oesophageal cancer and make him more fit for a gastrostomy.

4. It has recently been established that the older teaching on the absorption of proteins is incorrect. We used to be taught that they were absorbed principally as peptones. Now we believe they are absorbed principally as amino-acids. Peptonization therefore does not go far enough to render protein absorbable by the bowel.

The second and third of these arguments need not be elaborated further.

Analyses of the urine of patients "fed" on peptonized milk or peptonized egg albumen have been made by many workers, and are now sufficiently numerous to lead to some definite conclusions. Laidlaw and Ryffel found that the nitrogen output corresponded pretty closely to that of professional fasting men. Langdon Brown found no difference in the urinary nitrogen output (Kjeldahl's method), whether the patients were given normal saline or the following enema pancreatized for twenty minutes:

$$
\text { Milk, } 4 \text { oz. }
$$

Plasmon, 1 to 2 drachms.

Dextrose, 1 to 2 drachms.

Sod. bicarbonate, 20 grains.

Liq. pancreaticus, 1 drachm.

Tinct. opii, $m$ v.

Boyd and Robertson have published daily urinary analyses in seven cases fed on pancreatized milk or eggs. They found, as we have, that the output of nitrogen varies much in different patients; in our cases it appeared to depend on whether the patient had been dieting and starving before the attack of haematemesis. In the Edinburgh cases sufficient clinical data to determine this are not given. Taking these seven cases together, the average daily excretion of nitrogen during the week of rectal feeding was 5.7 grams. During their first week of starvation, Succi and Cetti, the professional fasting men, passed a daily average of 12.6 grams. No doubt they were fortified for the ordeal by previous good living, but it is evident that the rectal "feeding" was practical starvation for the women with gastric ulcer.

The writers have made daily urinary analyses in eight cases of gastric ulcer fed by nutrients of varying com. position.

Two patients were given raw milk nutrients. In one of these the average daily output of nitrogen from the second to the ninth day was 7 grams, as against the Succi and Cetti average of 11 grams. In the other case, the Bristol case showed a daily nitrogenous output from the eighth to the thirteenth day of 7.6 grams, as against the Succi average for the same period of 6.8 grams. A man was given nutrients of peptonized milk and somatose; his daily average output was 10 grams as against the SucciCetti average of 12.6 grams. In several of our cases the patients were given nothing but saline for a day or two, and then ordinary peptonized enemata, but these never stopped the starvation fall in the nitrogen output.

It is proved, therefore, that little if any nutriment is absorbed from a rectal injection containing albumen or peptone. This may be due to one of two causes: $(a)$ That the colon is unable to absorb proteins or the products of their digestion; or (b) that the colon lacks the power to convert peptone, which is not absorbable, into aminoacids.

Modern physiological research has revolutionized our conceptions of protein absorption. It is now believed that peptones are scarcely at all absorbed, but that the products of protein digestion pass through the epitheliai lining of the small intestine in the form of amino-acids as leucine, tyrosine, tryptophane, lysine, arginine, etc. Trypsin of pancreatic juice converts albumens into these amino. acids, and the ferment erepsin, in the succus entericus, can finish the work of the gastric juice and convert peptones (also caseinogen) into amino-acids. The ordinary nutrient enema is pancreatized for twenty minutes. In this time no amino-acids are split off. If we hope that the mixture of caseinogen, albumen, and peptone will be absorbed from the patient's rectum, we are assuming the presence of erepsin or trypsin in that particular person's rectum without evidence. If there is none there, absorp. tion is impossible. Now it is true that the faeces may contain trypsin, but there is no evidence that the colon of patients who are receiving no food by mouth contains either trypsin or erepsin.

It might be thought advisable to use Leube's method, and to introduce into the bowel a mixture of chopped pancreas and meat, In practice, however, this leads to grave putrefaction and toxaemia.

It occurred to us that before abandoning rectal feeding as useless it would be wise to try the effect of giving prolonged pancreatic digests containing amino-acids.

\section{Rectal Feecling with Amino-Acids.}

All our patients were suffering from gastric ulcer, and were treated by cutting off all food by the mouth, though water was allowed. The nutrients were varied in each case. The plan was to give either normal saline or milk 
peptonized for twenty minutes during the first three or four days, and then to change to milk pancreatized for twenty.four hours to see if it would interrupt the steady starvation fall in the output of nitrogen. In two cases we gave mixed amino-acids prepared by Merck by the action of strong sulphuric acid on proteins. This was, however, expensive, and only suitable for experimental purposes.

The enema we used most was prepared by boiling a pint of milk in a flask, adding two to four drachms of some reliable pancreatic preparation (some that we used were subsequently found to be inert), and keeping in the incubator for twenty-four hours, then boiling. From five to eight fluid ounces were given every six hours. A daily rectal wash-out was employed, but we did not analyse the washings. Instead, the nitrogen in the urine was estimated by Kjeldahl's method. The ammonia nitrogen was estimated by the formalin method by Dr. P. A. Opie.

\section{CASE I.}

Female, aged 25, suffering from gastric ulcer. Had been on peptonized milk by mouth for several days.

\begin{tabular}{|c|c|c|c|c|c|c|}
\hline Day. & By Mouth. & \multicolumn{2}{|c|}{ By Rectum. } & 号 & $\begin{array}{l}\text { Ammonia } \\
\text { per Cent. } \\
\text { of total N. }\end{array}$ & $\begin{array}{c}\text { Daily } \\
\text { N Output } \\
\text { in Grams }\end{array}$ \\
\hline 1st & Water & \multicolumn{2}{|c|}{ Saline and glucose } & oz. & - & 8.03 \\
\hline 2nd & Water & ,, & " & 22 & 3.2 & 6.28 \\
\hline $3 \mathrm{rd}$ & Water & , & .. & 26 & 0.8 & 4.36 \\
\hline 44th & Water & ," & , & 26 & 12.3 & 5.56 \\
\hline 5 th & Water & \multirow{2}{*}{\multicolumn{2}{|c|}{$\begin{array}{l}\text { Peptonizeā milk } 24 \text { hrs. } \\
\quad(6 \text { oz. } 4 \text { hourly })\end{array}$}} & 16 & 12.7 & 7.66 \\
\hline 6 th & Water & & & 22 & 12.5 & 5.91 \\
\hline 7th & Water & .. & 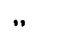 & 32 & 9.3 & 9.53 \\
\hline 8th & $\begin{array}{l}\text { Peptonized } \\
\text { milk }\end{array}$ & - & & 31 & 0.5 & 9.02 \\
\hline
\end{tabular}
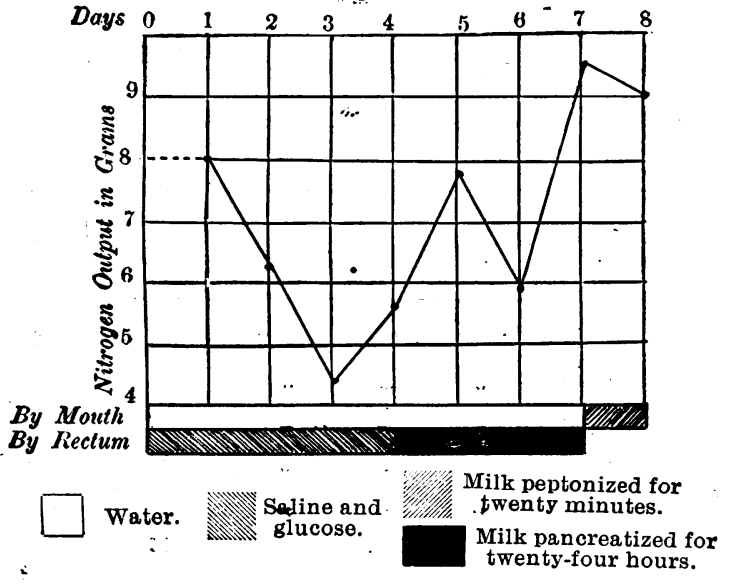

CAsi II.

Man with gastric ulcer. Had been taking full diet up to day of haematemesis.

\begin{tabular}{|c|c|c|c|c|c|c|c|}
\hline Day. & By Mouth. & \multicolumn{3}{|c|}{ By Rectum. } & $\stackrel{\dot{\Xi}}{\stackrel{\Xi}{\infty}}$ & $\begin{array}{c}\text { Ammonia } \\
\text { per Cent. } \\
\text { of totail N. }\end{array}$ & $\begin{array}{c}\text { Daily } \\
\text { N Output } \\
\text { in Grams }\end{array}$ \\
\hline lst & Milk & \multicolumn{3}{|c|}{-} & 21 & 1.4 & 14.3 \\
\hline $2 n d$ & Water & \multicolumn{3}{|c|}{ Saline } & 19 & 2.9 & 10.7 \\
\hline 3rd & Water & \multicolumn{3}{|c|}{$\begin{array}{c}\text { Peptonized milk } 20 \text { min. } \\
(5 \text { oz. } 6 \text { hourly })\end{array}$} & 21 & 3.5 & 9.6 \\
\hline 4 th & Water & " & " & " & 20 & 4.8 & 6.8 \\
\hline 5 th & Water & $"$ & & " & 16 & 2.9 & 7.9 \\
\hline 6th & Water & \multicolumn{3}{|c|}{$\begin{array}{l}\text { Peptonized milk } 24 \text { hrs., } \\
\text { "3j glucose }(5 \text { oz. } 6 \text { hourly }\end{array}$} & 10 & 2.9 & 7.2 \\
\hline 7th & Water & " & " & " & 21 & 3.0 & 14.4 \\
\hline 8th & Water & $"$ & " & " & 15 & 3.7 & 11.2 \\
\hline 9th & $\begin{array}{c}\text { Peptonized } \\
\text { milk }\end{array}$ & & 23 & 2.8 & 16.1 \\
\hline 10th & $\underset{\text { milk }}{\text { Peptonized }}$ & & & & 54 & 0.9 & 13.7 \\
\hline
\end{tabular}
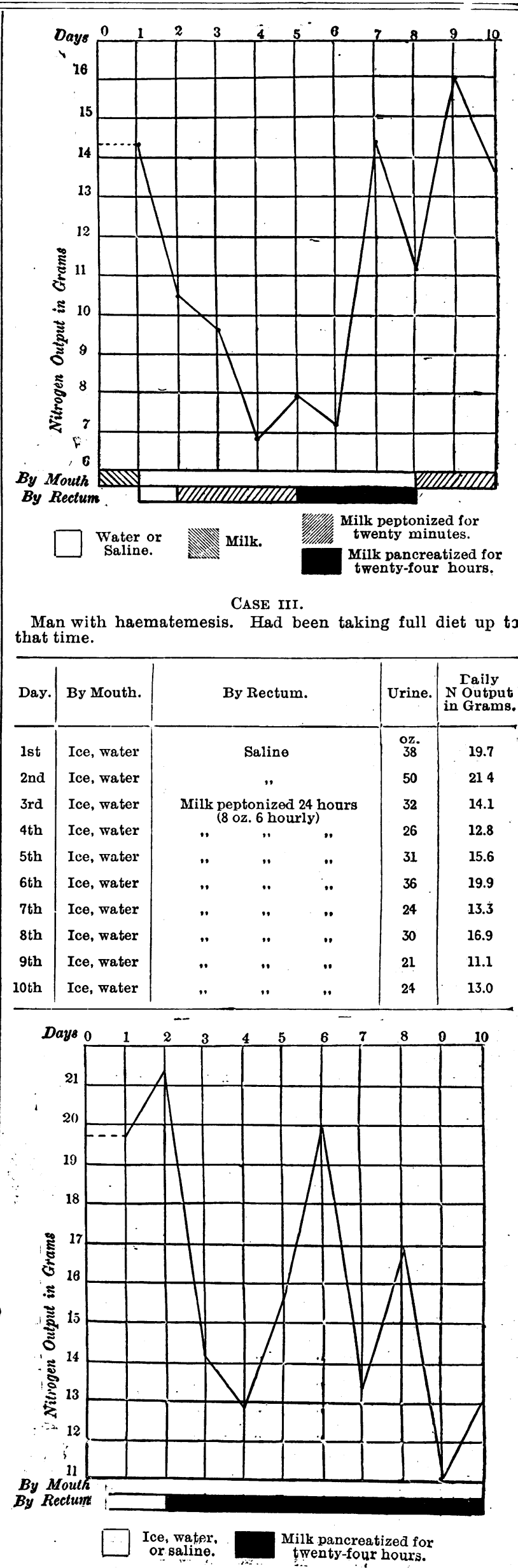
CASE IV.

Man with haematemesis. On very scanty diet for three days before admission.

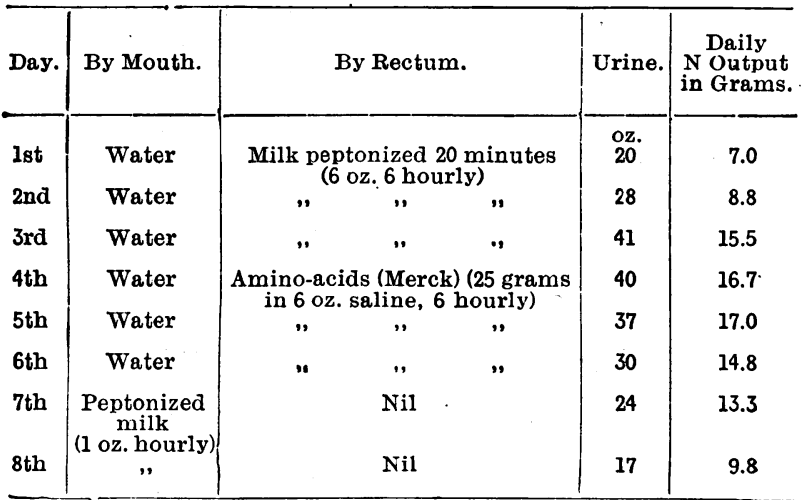

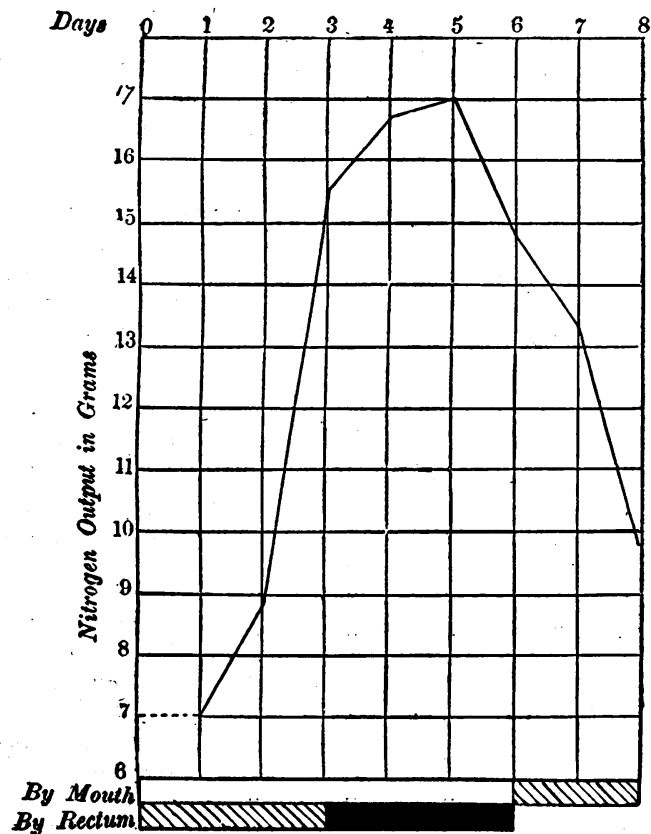

Water. Milk peptonized for Amino-acids twenty minutes. in saline.

CASE V.

Man, aged 24, admitted for haematemesis. On full diet up to that time.

\begin{tabular}{|c|c|c|c|c|c|c|}
\hline Day. & By Mouth. & \multicolumn{3}{|c|}{ By Rectum. } & Urine: & $\begin{array}{c}\text { Daily } \\
\text { N Output } \\
\text { in Grams. }\end{array}$ \\
\hline 1st & Water & \multicolumn{3}{|c|}{$\begin{array}{l}\text { Milk peptonized } 20 \text { minutes } \\
\text { ( } 5 \text { oz. } 4 \text { hourly) }\end{array}$} & oz. & 12.9 \\
\hline 2nd & Water & " & $"$ & " & 18 & 12.5 \\
\hline $3 \mathbf{r d}$ & Water & " & " & ") & 20 & 14.8 \\
\hline 4th & Water & $"$ & $\oplus$ & " & 19 & 13.9 \\
\hline 5th & Water & " & " & $"$ & 20 & 14.6 \\
\hline 6th & Water & \multicolumn{3}{|c|}{ Peptonized milk 24 hours } & 15 & 10.6 \\
\hline 7th & Water & \multicolumn{3}{|c|}{$\begin{array}{c}\text { Amino-acids } 4 \text { per cent., glucose } \\
3 \text { per cent. ( } 5 \text { oz. } 4 \text { hourly) }\end{array}$} & 16 & 11.1 \\
\hline 8th & Water & ," & " & " & 16 & 11.5 \\
\hline 9th & Water & " & ", & " & 15 & 10.9 \\
\hline
\end{tabular}

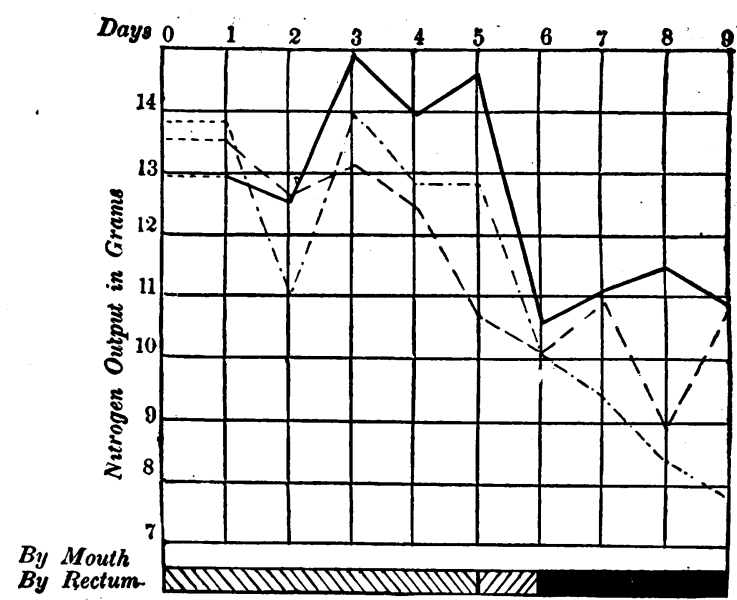

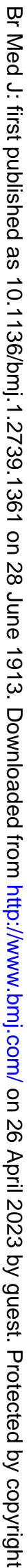

In none of the above cases was any rectal irritation produced, either by the long-peptonized milk or by the amino-acids.

The three following cases serve for purposes of com. parison. In two of them it was intended that they should be repetitions of the method used for Case II, but it was found afterwards that the preparation of pancreas used was absolutely inert.

CASE vi.

Female, aged 24, admitted for haematemesis. Well fed up to date of admission. Menstruating for first seven days; no observations. During this time she had nutrients of unpeptonized milk.

\begin{tabular}{|c|c|c|c|c|c|c|}
\hline Day. & By Mouth. & \multicolumn{3}{|c|}{ By Rectum. } & Urine. & $\begin{array}{c}\text { Daily } \\
\text { N Output } \\
\text { in Grams. }\end{array}$ \\
\hline 8th & Water & \multicolumn{3}{|c|}{ Raw milk (1 pint a day) } & $\begin{array}{l}\text { Oz. } \\
26\end{array}$ & 10.4 \\
\hline 9th & Water & " & n & " & 24 & 9.1 \\
\hline 10 th & Water & " & ", & " & $26^{*}$ & 6.1 \\
\hline 11th & Water & " & " & $\omega$ & 18 & 8.0 \\
\hline 12th & Water & " & ". & * & 18 & 8.0 \\
\hline 13th & $\begin{array}{l}\text { Peptonized } \\
\text { milk }\end{array}$ & \multicolumn{3}{|c|}{$\mathrm{Nil}^{-}$} & 16 & 5.5 \\
\hline
\end{tabular}

${ }^{*}$ A few ounces lost.

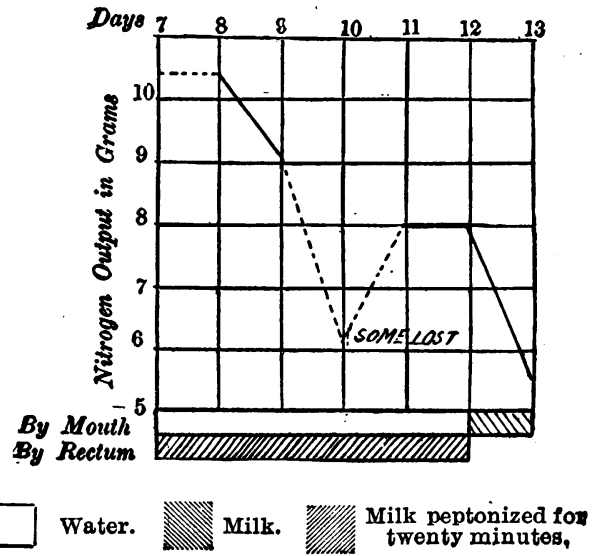


CASE vir.

Female, aged 27, with haematemesis. Had been well fed till then.

\begin{tabular}{|c|c|c|c|c|c|c|}
\hline Day. & By Mouth. & \multicolumn{3}{|c|}{ By Rectum. } & Urine. & $\begin{array}{l}\text { Daily } \\
\text { N Output } \\
\text { in Grams. }\end{array}$ \\
\hline lst & Water & \multicolumn{3}{|c|}{ Raw milk (5 oz. 4 hourly) } & $\begin{array}{l}\text { oz. } \\
16\end{array}$ & - \\
\hline 2nd & Water & , & " & , & 28 & 14.8 \\
\hline 3 rd & Water & " & ", & " & 15 & 5.5 \\
\hline 4th & Water & , & , & , & 16 & 8.2 \\
\hline 5th & Water & , & , & , & 14 & 6.5 \\
\hline 6th & Water & ", & ," & , & 18 & 3.9 \\
\hline 7th & Water & ", & ," & " & (Lost) & - \\
\hline 8 th & Water & " & ", & " & 19 & 6.6 \\
\hline 9th & Water & $\because$ & " & " & 27 & 5.2 \\
\hline
\end{tabular}

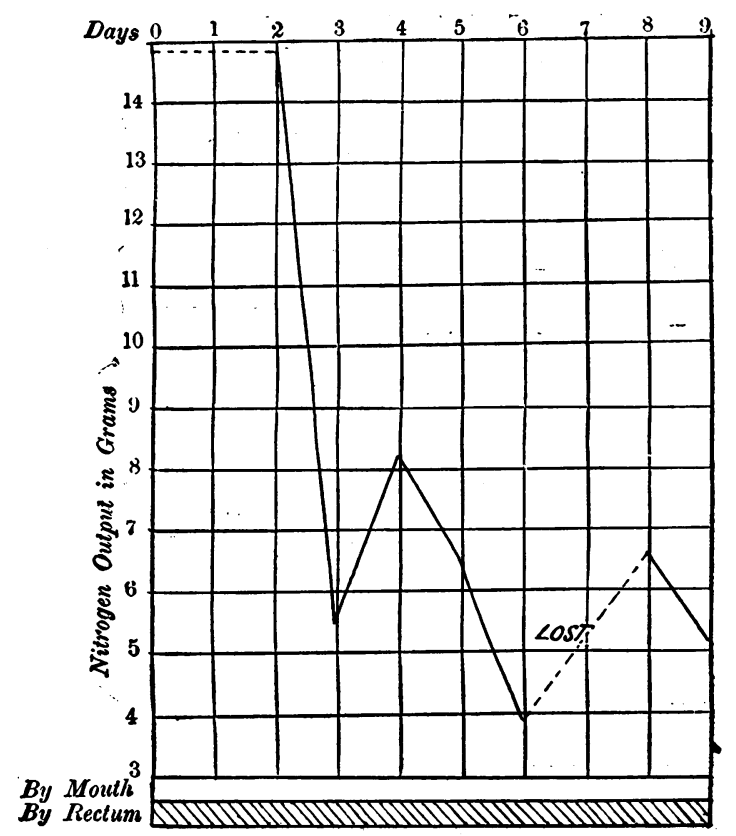

Water. Milk.

Case viIr.

Man with gastric ulcer. Had been well fed up to time of "admission.

\begin{tabular}{|c|c|c|c|c|c|c|}
\hline Day. & By Mouth. & \multicolumn{3}{|c|}{ By Rectum. } & Urine. & $\begin{array}{l}\text { Daily } \\
\mathrm{N} \text { Output } \\
\text { in Grams. }\end{array}$ \\
\hline 1st & & \multicolumn{3}{|c|}{$\begin{array}{l}\text { Milk peptonized } 20 \text { minutes; } \\
\text { somatose ( } 4 \mathrm{oz} .6 \text { hourly) }\end{array}$} & oz. & 14.7 \\
\hline $2 n d$ & Water & " & " & " & 40 & 14.4 \\
\hline $3 r d$ & Water & $"$ & ", & $"$ & 28 & 9.1 \\
\hline 4 th & Water & $"$ & " & " & 21 & 5.7 \\
\hline 5 th & Water & " & ", & " & 40 & 9.8 \\
\hline 6th & Water & ", & " & " : & 35 & 10.2 \\
\hline 7th & Water & ", & ", & ", & 21 & 7.4 \\
\hline
\end{tabular}

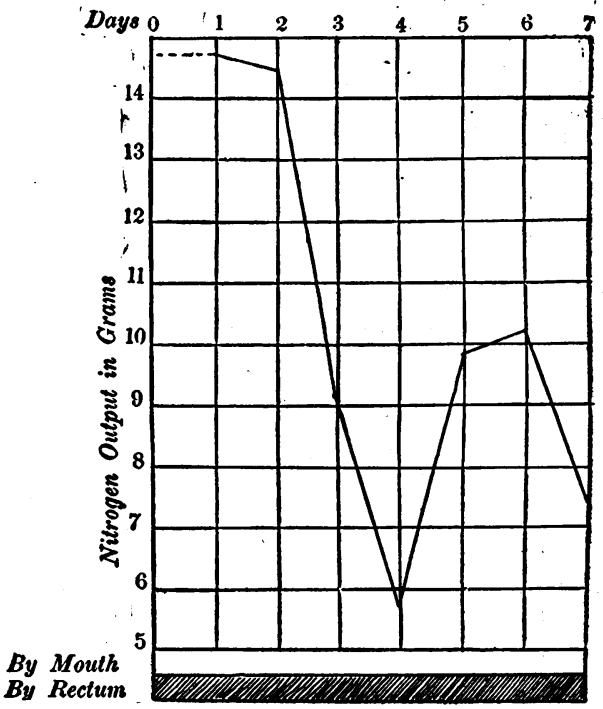

Water.

Milk peptonized for twent minutes + somatose.

On studying the records of these cases, it is to be observed first that it takes about twenty-four hours for the urine to show any response to improvement in the feeding in most cases. We have observed in these and other unpublished observations that the rise in the nitrogen output when sufficient mouth-feeding is resumed usually takes that time to develop. We notice, secondly, in Cases I, II, and IV, a very striking rise in the nitrogen output as soon as the patient is put on amino-acid nutrients, whether given as milk long peptonized or as artificial mixed amino-acids. This rise takes place at the time when there is usually a fall if no nourishment is being absorbed. Again, we observe in Case III, fed after the first two days on milk peptonized for twenty-four hours, that the nitrogen output maintains an extraordinarily high level, far higher than Succi's, Cetti's, our Cases vir and virr, or Boyd and Robertson's seven cases. We are bound to conclude, therefore, that in these four patients amino-acids were undoubtedly absorbed from the large bowel in very considerable quantity. Clinically all the cases did most satisfactorily. They kept very fit and had little or no rectal trouble.

Our Case v demands a few words of special reference. It was in a different hospital, and the amino-acids were not keeping very well when they were brought into use. Apparently he did not absorb as much nutriment as the other patients. It is possible that this may have been due to some fault in the mode of administration. Although this case does not show the rise in the output of urinary nitrogen which is so striking in Cases I, II, and IV, it will be observed that the figures for the later days are higher than those of Succi and Cetti, although they were prepared for their fast:

\begin{tabular}{cccc|c|c|c}
\hline \multicolumn{1}{c|}{ Day. } & & $\begin{array}{c}\text { Patient given } \\
\text { Amino-acids. }\end{array}$ & Succi. & Cetti. \\
\hline 6th & $\ldots$ & $\ldots$ & $\ldots$ & $\begin{array}{c}\text { Grams. } \\
10.6\end{array}$ & $\begin{array}{c}\text { Grams. } \\
10.1\end{array}$ & $\begin{array}{c}\text { Grams. } \\
10.1\end{array}$ \\
7 th & $\ldots$ & $\ldots$ & $\ldots$ & 11.1 & 9.4 & 10.9 \\
8 th & $\ldots$ & $\ldots$ & $\ldots$ & 11.5 & 8.4 & 8.9 \\
9 th & $\ldots$ & $\ldots$ & $\ldots$ & 10.9 & 7.8 & 10.8 \\
\hline
\end{tabular}

A criticism has been brought against the results, that perchance the amino-acids were so broken down by putrefaction that they could not be assimilated by the tissues after absorption, but simply ran to waste in the urine. The milk, however, if boiled before the twentyfour hours' pancreatization, kept perfectly sweet. If comparatively simple putrefactive bodies were absorbed and excreted, the ammonia nitrogen in the urine must have shown a rise; but it will be observed in Case 1 that the ammonia nitrogen was only a fraction higher on the three amino-acid days than on the fourth. In Case II the 
evidence is yet more convincing, as the ammonia nitrogen was lower on the three amino-acid days than on the three days preceding. Free amino-acids, of course, would appear in the urinary analysis by the formalin method as ammonia nitrogen.

It might be argued that the products of protein digestion absorbed were converted into urea by the liver and not assimilated by the tissues, and this it appears im. possible to refute; but there is no reason to suppose, if amino-acids are absorbed at all, that they should not be any less nourishing to the tissues when they enter by the rectum than when they enter by the small intestine. The rectal washings were not putrefactive.

We did not weigh our patients, partly because it was difficult in view of their ailment, and also because we believe that any loss of weight is masked by the absorption of water.

The Absorption of Sugars.

The two sugars with which most experimenters have worked are lactose and dextrose, the former in milk and the latter in pure solution. It is important to use it chemically pure, or it will probably be irritating.

There are two reliable means of estimating the amount of sugar absorbed into the blood. One is to determine the ammonia nitrogen in the urine, which only rises to a high figure when the sugar is very deficient. The other is to measure the respiratory quotient by analysing the expired air. The quotient is raised by carbohydrate feeding.

Reach found that a small inconstant rise in the respiratory quotient takes place after giving dextrine or dextrose by the rectum, but much less than after giving the same quantity by the mouth.

One of us* has published determinations of the ammonia nitrogen on two patients "fed" on nutrient enemata containing lactose in mill. The anmonia nitrogen soon rose to a very high figure (15 to 17 per cent.). This would appear to indicate that lactose is badly absorbed.

Dextrose undoubtedly controls the acidosis causing the rise of ammonia nitrogen very effectually. In our Cases I and II, so long as the glucose was well retained the ammonia nitrogen kept very low. This has been abundantly proved by other worliers.

Although we attach no importance to the analysis of rectal washings in calculating the absorption of nitrogen, we are prepared to admit that Boyd and Robertson's arguments derived from this method of experimentation in favour of cextrose absorption are valid. The bulk of the protein they administered could always be recovered from the rectal washings, but the sugar had almost entirely, in two cases entirely, disappeared. They show conclusively that this cannot be accounted for by putre factive changes. Deucher, Plantenga, and Zehmisch all obtained absorption of the great bulk of the sugar given per rectum.

Mutch and $R y f f e l$ have recently confirmed these results. Scarcely any sugar could be recovered in the rectal washings after 6 per cent. glucose enemata had been given.

Dextrose is, of course, a very valuable food, and the demonstration that it can be absorbed by the rectum opens up an important means of feeding patients who cannot take anything by the mouth.

\section{The Absorption of Fat.}

We have made no special observations on the absorption of fat, but a brief summary of our lnowledge on this subject is included.

Deucher and other workers found a small absorption, but in their cases fat was being taken by mouth as well as by the rectum.

Boyd and Robertson used the unsatisfactory "washout" method, and felt justified in concluding that the fat which they failed to recover must have been absorbed. How little reliable this is one of their cases showed, in which more fat was found in the washings than was given in the enema. In three of their patients they considered that a good deal of fat was absorbed (as much as 7 grams a day in one case), and they believed that the more they gave the more was retained. *A. Rendle Short, The New Physiology in Surgical and General
Practice. Second edition (Messis. J. Wright and Co. 1912.), p. 225 .
The most reliable observations are those in which it has been possible to estimate the fat in the chyle from the thoracic duct. Munk and Rosenstein used a case in which the chyle could be collected from a lymphatic fistula. On a fat-poor diet an enema of 15 grams of lipanin was given; the lymph showed a rise in fat contents from 0.18 per cent. to 0.45 per cent., about 3.7 per cent. of the oil being absorbed. In another experiment 5.5 per cent. was absorbed. Even when fat is given by the mouth, only about half of it can be recovered from the thoracic duct, so that these figures might probably be doubled to represent the actual absorption.

Langdon Brown mentions a case of filarial chyluria in which nutrients of olive oil and of milk failed to get absorbed sufficiently to appear as fatty droplets in the urine.

We must conclude, then, that the power of fat absorption by the rectum is only slight. If it is intended to take advantage of it, cod-liver oil should be given. Boyd and Robertson, as well as Langdon Brown, show that the quantity absorbed from milk is negligible.

General Considerations.

In using rectal injections as a means of treatment for gastric ulcer, or after operations on the stomach, it must not be imagined that that organ is given complete rest. Umber has shown on a patient with a gastrostomy that there is a copious gastric secretion after a nutrient enema, the total acidity being 30 and the $\mathrm{HCl} 20$. Probably this accounts for the dyspeptic pain suffered by patients with gastric ulcer after each enema.

Eggs are not desirable constituents of a rectal feed: The sulphuretted hydrogen liberated from them is unpleasant for the attendants, and probably harmful to the patient.

We consider that the best form of nutrient enema should be prepared as follows:

To a pint and a half of milk, boiled and cooled, add $\frac{1}{2}$ oz. of some reliable pancreatic fluid, or four pancreatic tablets. Keep in the incubator twenty-four hours. Add $1 \frac{1}{2}$ oz. of pure dextrose. Give $5 \mathrm{oz}$. every four hours, or, if the patient can retain it, $10 \mathrm{oz}$. every eight hours.

Conclusions.

1. The older observations on the absorption of foodstufts from rectal enemata, based on the analysis of rectal " wash-outs," are unreliable.

2. The daily output of nitrogen in the urine of patients given nutrient enemata of mill or eggs peptonized for twenty or thirty minutes demonstrates that almost no nitrogenous matter is absorbed.

3. Modern physiological opinion holds that proteins are absorbed principally as amino-acids. The failure of the rectum to absorb ordinary nutrient enemata is largely due to the fact that peptones are given instead of aminoacids.

4. Chemically prepared amino-acids, or milk pancreatized for twenty-four hours so that amino-acids are separated, allows of a much better absorption of nitrogenous foodstuffs from the rectum, as demonstrated in tive cases by the high nitrogen output in the urine.

5. The low output of ammonia nitrogen shows that this high output was not due to the absorption of putrefactive bodies. The rectal washings were not offensive.

6. Dextrose is much better absorbed than lactose, and relieves the acidosis of starvation.

7. Fat is not well absorbed. Scarcely any of the fat of ordinary milk enemata is retained.

8. The best nutrient enema consists of milk pancreatized for twenty-four hours, with 5 per cent. pure dextrose.

We are greatly indebted to Dr. P. A. Opie and Dr. W. A. Reynolds for help in obtaining clinical material.

Bieliography.

Boyd and Robertson: Scottish Mecl. and Suraical Journal, 1906, p. 193. prown, Langdon: Trans. Roy. Soc. MIed., 1911, Therapeut. Section. p. 63.

Deucher: Deut Arch für klin. Med, vol. 1viii, 1897, S. 210 Ewald: Zeit. für klin. Med., Bd. 12, 1887, S. 407.

Edsall and Miller: Trans. Coll. of Physicians, Philadelphia: vol. Xxiv, 1902, p. 225 .

Gilles de la Tourette: Traité clinique et thérapeutique de l'hystérie. p. 361 .

Gros: Traitement de certaines Maladies de l'estomac par la cure de repose absolu et prolongé de l'estomac avec alimentation rectalo exclusive, 1898. 
Groves and Walker Hall: Proc. Roy. Soc. Med., vol. ii, 1909, Part III, Surgical Section, p. 121

Huber: Deut. Arch. fïr klin. Med., Bd. 47, 1891. S. 495. Leube: Deut. Arch für 7klin. Med.. Bd 10, 1872 S. 1 .

Munk and Rosenstein ; Virchow's Archiv, Bd. 123, 1891, S. 484 Mutch and Ryffel: Guy's Hospital Reports, 1912, vol. lxvi, p. 223. Plantenga: Diss., Freiburg, 1898.

Reach : Archiv fiir exp. Path. u. Pharm., Bd. 47, 1902, S. 231.

Unber : Berl. klin. Woch., 1905, No. 3, S. 56

\section{THE EXPERIENCES OF A MEDICAI ADVISER UNDER THF INSURANCE ACT.}

$B Y$

BERTRAM M. H. ROGERS, B.A., M.D., B.Ch.Oxon., BRISTOL.

IT may be of interest to Insurance Committees who ars considering the advisability of appointing a medical adviser, and to the profession generally, if I give a short account of my experiences in that capacity, based on the first hundred cases sent to me for my opinion. The duties that have been imposed upon me are to see and examine any insured person sent either by a medical man or by one of the friendly societies, and to report to the Insurance Committee my opinion as to whether the person sent is fit or not to work; perhaps it may be put thus-to decide whether a person complaining of certain symptoms and alleging that he or she is unfit to return to work is fit. On my decision depends the payment of or refusal to pay sickness benefits, as far as regard the friendly societies, while it relieves the doctor of the unpleasant duty of refusing to sign any more sick certificates, an act which often makes him very unpopular in his district, as the matter is soon spread abroad.

My appointment dates from February 12th, but the doctors and the societies did not at first seem to appreciate the post, or perhaps to understand in what manner I might be made use of, for in the first few weels no cases were sent to me. When they did, there was no mistaking the fact, as the cases came rolling in, so that by May 15 th one hundred had been told off to come to me. The exact figures are: From March $5 \mathrm{th}$, the day of my first case, to the end of the month, 22 ; in April, 50; while the remaining 28 came in the first fifteen days of May. Since then I have had 64 more, so that the number for the last four weelss is greater than any preceding four.

It must be remembered that there is nothing in the Act to compel any one to come; an insured person receiving a letter telling him or her to come to my house for examination can ignore it. No doubt they think it part of the Act, and fear some penalty if they neglect the order. Of course, they run the risk of having further payments refused by their society, and a few do abstain from coming or giving any reason for not appearing. On the other hand, many express their wish to be examined and seem to look on a visit to mo as a sort of consultation on their case. So far I have not had any difficulty with any one. I have had an abusive letter from one alcoholic person whom I reported as fit to work, but that is the only case, though no doubt several have not been best pleased with my decision. I am confident if one treats these people with courtesy and does not charge each and every one with being a malingerer that unpleasantness will be the exception; they may not like my report, but I hope they recognize that my opinion was come to fairly and after duly weighing the facts they gave me. This want of power to compel an examination by a doctor specially appointed should be altered, in my opinion, and the Act made uniform with the Workmen's Compensation Act. My duty is not to act as a consultant, as is generally understood by that term, but melely to decide whether or not a person is fit to work.

The method is as follows: All references, whether from a doctor or a friendly society, for a person to come to me, are sent to the office of the Insurance Committee. The doctors have a printed form something like that used for the notification of infectious diseases; the societies write a letter to the clerk. All these references are telephoned to me and I give instructions on what day the person is to be told to come to see me and the hour. Generally I fix the next day, for I look on all cases as urgent, and $I$ see them all at my house. I have had a little grumbling about this, as it often involves a long tram journey and the expenditure of some pence, which I fear some can ill afford; but as long as the post is a part-time one, my convenience must be considered both as regards time and place, though I am willing to make such arrangements as are possible for the insured persons. The question whether this post should be a whole-time one has been considered, and at present we in Bristol are not in favour of it being so, and for the following reasons: First, we are not too fond of the official doctor; secondly, we prefer to have one of ourselves in the position of adviser, and (though I say it of myself) one who is acceptable to the local profession; thirdly, the salary must be sufficiently large to make it worth the while of a medical man of some position and standing to give up his private work, for it is no light matter to ask a doctor to throw over his friends and patients after many years of attendance; there must, too, be some fixity of tenure, for the holder of the post cannot render himself liable to be turned out at the caprice of the Insurance Committee to pick up what shreds of practice he can gather after being for some years out of private work; and, lastly, there is the question of a pension. My salary is at present paid out of the local funds, but this may be altered if the Commissioners will take it over.

On the receipt of a note giving the name, address, and detail of the insured person, and the name of the doctor in attendance, I write to the latter and ask if he wishes to communicate anything to me about his patient. I generally get a letter or message giving me much useful information, which is of very material help to me. When the case has been referred by a doctor, this is not neces. sary, as a few notes are made on the notification paper. This, of course, involves a great deal of letter writing, for I always write to the doctor again after seeing the insured person to tell him what decision I have come to. There is, further, the report to the Committee. This latter body sends my report to the society the insured perscn was in.

Coming now to my figures, my hundred consisted of 43 males and 57 females, on whom the following reports were sent:

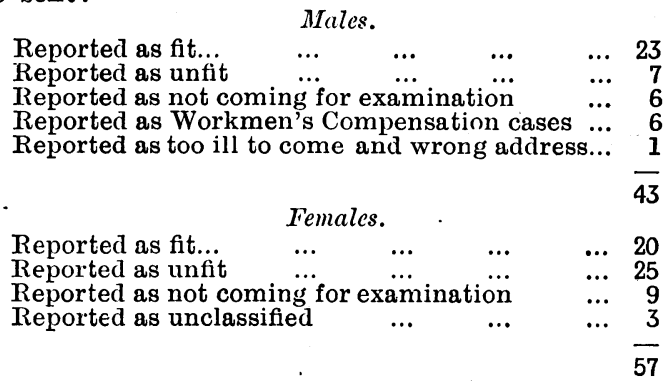

One or two remarks may be made on these tables. I find that some doctors do not recognize that I have, in my capacity as medical adviser, nothing to do with Workmen's Compensation cases. The distinction is easily made, for if a workman is in receipt of pay from his employer for an accident received in the course of his work, then the Insurance Act does not come in, though the man may be in receipt of pay from his club. The unclassified cases are as follows:

1. The woman received an accident between the time of reporting her to me and the time she was told to come.

2. The officious action of a health visitor.

3. A case in which I had some correspondence about the action of a doctor in refusing to give a certificate for more than one day.

So far the friendly societies have made more use of mo than the doctors, as they have sent me 59 and the latter 41. In my second hundred, as far as I have gone, this dis. proportion is more marked, for out of 64 the doctors have only sent me 6 . Some societies are very. active, partly, no doubt, because they have a much larger number on their books than others, but in the first hundred tro societies sent me 15 each. Sufficient care is not exercised yet in referring the cases to me, for I have had several who were obviously too ill to work, but as I found 43 fit out of 100 and only 32 unfit, there is not much to complain of.

The number of malingerers is very small; all have had 